\title{
THE IMPACT OF OCCUPATIONAL SEGREGATION ON OCCUPATIONAL GENDER PAY GAP IN THE EUROPEAN UNION
}

\author{
Bianca BULIGESCU1 \\ Lex BORGHANS 2 \\ Didier FOUARGE ${ }^{3}$ \\ DOI: $10.35782 / J C P P .2020 .4 .05$
}

\begin{abstract}
The aim of this paper is to analyse the relationship between wages and the fraction of women in an occupation, using variation in the female participation in occupations across European countries. Using data from the European Structure of Earnings Survey 2006 with information about the wages in 93 occupations in 10 countries, we investigate how the wages of men and women and therefore the gender wage gap varies when the fraction of women increases. $W$ allow for non-linearities in this relationship. In the raw data we find that mixed occupations pay better than occupations in which mainly men or mainly women are working, but controlling for occupation the picture reverses and we find that especially occupations with a high fraction of women pay more than mixed occupations. Female earnings are almost similar to male earnings when the fraction of women goes down and vice versa, but the effect is stronger in the female occupations, giving men an advantage in the labour market..
\end{abstract}

Keywords: gender segregation, gender wage gap, occupational wages

\section{Introduction}

The gender wage gap, the difference in pay between women and men, is for a substantial part explained by the different occupation men and women work in (occupational segregation). This leads to the question whether on the one hand women self-select into occupations that require fewer skills or are intrinsically more attractive

1 Research Institute for Quality of Life, Romanian Academy of Science.

We wish to thank EUROSTAT staff members Simone Casali, Edwin Schaaf and Didier Dupré for making this research possible by providing access to the data, for their help and for their hospitality. The authors are responsible for all remaining errors. Corresponding author is Bianca Buligescu (bianca.buligescu@iccv.ro).

2 Faculty of Business and Administration, ROA, Maastricht University.

3 School of Business and Economics, ROA, Maastricht University. 
and therefore require less pay as compensation, or on the other hand wages in female jobs are lower because of the presence of many women. Since it is impossible to fully characterize occupations in order to control for such variation, more insight could be gained when the fraction of women in occupations could be varied. To answer this question this paper uses data from the European Structure of Earnings Survey 2006 with information about the wages in 93 occupations in 10 countries. We investigate how the wages of men and women and therefore the gender wage gap varies when the fraction of women increases. This paper brings to the existing literature three novelties: first, the research strategy used to rely on cross country variation is new, second, it allows for non-linearity in the effect of occupational segregation on the gender wage gap as most papers find a negative effect and third, the study is conducted at a detailed occupational ISCO 3 digits, while few studies in the world are conducted like this due to the fact that they require a huge sample (Strawinski, et al., 2018).

First, the research strategy relies on cross-country variation in order to find a causal effect which is new to the literature. We assume that occupational characteristics are the same across European countries and therefore the quality of the occupation and skills associated with it are held fixed. Further we assume that skills differences are similar across countries for each gender and we control for skills and all possible occupational characteristics. The tastes and preferences for a certain occupation can vary across countries. However, we assume that, on average, selection of women into occupations would be similar across European countries given common past and shared values. All these assumptions allow us to recover the causal effect.

Second, the functional form of the relationship between occupational segregation and the gender wage gap is not straightforward (Strawinski et al., 2018). Most papers argue that the relationship is linear, meaning that female occupations pay less than male occupations (for a review see Perales, 2010). Few other papers find a non-linear relationship between sex composition and wages where the highest wages for both men and women are earned in mixed or integrated occupations (Cotter et al., 2004; Hakim, 1998 cited in Strawinski et al., 2018; Magnusson, 2013).

Third, due to lack of comparable data across countries, few studies look at gender differentials due to occupational segregation in an international perspective (Burchell et al., 2014; Plasman, Sissoko, 2004; Hook, Petit 2008, Oostendorp, 2004). In the raw data we find that mixed occupations pay better than occupations in which mainly men or mainly women are working, but controlling for occupation the picture reverses and we find that especially occupations with a high fraction of women pay more than mixed occupations.

This paper contributes to the literature about the role of segregation in the gender wage gap. Despite a significant reduction in the differences in pay between males and females in a number of European Countries over the past decades, the differential in pay is still significant and the occupational segregation large (Burchell et al., 2014, Plasman, Sissoko 2004). Occupational segregation has been identified as one of the important factors responsible for the persistence of gender pay gap and therefore investigating the relationship between occupational segregation and gender pay gap is important from a policy perspective (Gupta, 1993). 
The remainder of this paper is organized as follows. Section 2 provides a brief overview of the theories and recent empirical findings concerning the relationship between occupational segregation and gender pay gap. Section 3 provides a description of the methodology used in this study, its main assumptions and the implications. Section 4 describes the European structure of earnings data, its strengths and limitations. Section 5 discusses the results. And section 6 concludes by discussing the relevance of this study in light of the previous literature.

\section{A Brief Literature Review}

The gender pay gap is the differential in pay between men and women. The unadjusted gender pay gap shows the difference between average gross hourly earnings of women paid employees as a percentage of average gross hourly earnings of men paid employees. According to Blau and Kahn (2017: 791), in the USA, by 2014, women fulltime workers earned about 79 percent of what men did on an annual basis and about 83 percent on a weekly basis. In the EU, in 2020 , the gender pay gap accounted for $85.2 \%$ in the unadjusted form: that is, women earn $14.8 \%$ less than men for both full-time and part-time workers ${ }^{1}$. The gender wage gap has significantly decreased during the last three decades. Brynin and Perales (2016:163) link the narrowing of the gender wage gap as the result of the growth in female skills, the spread of egalitarian gender ideologies and mainstreaming policies.

Blau and Kahn (2017: 826) report that while the Duncan Segregation Index ${ }^{2}$ declined by over 10 percentage points in the 1970s and 1980s, it declined by just over 3 percentage points in the following two decades (Baker, Cornelson, 2018). The index tells us that the overall segregation of males and females remains substantial: in recent years, over half of men (or women) in the USA would need to change occupations for the occupational distributions of male and female employment to be the same (Baker, Cornelson, 2018). In the EU 27, the index was 50.9 in 2007 , lower by almost $2 \%$ compared to the USA, however there are substantial country differences. Austria, the Czech Republic, Denmark, Norway, Sweden and the United Kingdom experienced relatively fast de-segregation. In contrast, segregation increased in Bulgaria, Ireland, Italy, Latvia, Romania and Spain (Bettio, Verashchagina 2009). Blau and Kahn (2017) find that, since the 1970s, in the USA, women have reduced (but not eliminated) their overrepresentation in administrative support and service jobs like teaching and nursing and made significant inroads into management and male professions. In the EU, the women's share within some occupations is still minor, for example in constructions, engineering, ICT, building and related trades, electrical and electronic trades, metal, machinery and related trades, agriculture, machinery mechanics etc. (Council of the European Union, European Institute for Gender Equality, 2017). Professions in

\footnotetext{
1 The USA figure and the EU figure are not directly comparable as they are calculated differently, but they give an indication of the importance of the gender pay gap.

2 The Duncan Segregation Index measures occupational segregation. It ranges from 0 to 100, where 0 indicates no segregation and 100 complete segregation. It calculates the percentage of women who would have to change jobs for the occupational distribution of women and men to be the same.
} 
healthcare, law and human resources are examples of higher-level occupations in which women's presence has greatly increased (Council of the European Union, European Institute for Gender Equality, 2017). Female dominated occupations are in pre-primary education, nursing or midwifery, secretarial and personal care work, domestic and related help etc. ${ }^{1}$ (Council of European Union, European Institute for Gender Equality, 2017). Burchell et al. (2014) find that $18 \%$ of women work in mixed occupations, $69 \%$ of women work in female dominated occupations and 13\% work in male dominated occupations. By contrast, $15 \%$ of men work in mixed occupations, $59 \%$ work in male dominated occupations and 26\% work in female dominated occupations. Therefore, there is still substantial occupational segregation in the European Union.

Despite the decrease, changes in the occupational structure have benefited exclusively high educated women having graduate jobs (Blau, Kahn, 2017; Brynin, Perales, 2016). Conventional human capital variables taken together explain little of the wage gap, due to a convergence in education between men and women (ILO, 2018), while gender differences in occupation and industry ${ }^{2}$ continue to be important and they explain substantially more than newer explanations based on psychological attributes and noncognitive skills (Bettio, Verashchagina, 2009; Blau and Kahn 2017; Goldin, 2014; Levanon, Grusky, 2016). Blau and Kahn (2017: 827) find that occupations explain 1/3 of the gender wage gap and together with industry they explain half of the gender wage gap. The gender wage gap is for a substantial part explained by the different occupation men and women work in.

There are seven theories which can explain the relationship between occupational segregation and the gender wage gap: human capital, discrimination, compensating wage differentials, non-compensating wage differentials, crowding, devaluation and the role of the trade unions as institutions which have a role in reducing the gender pay gap.

The first theory is that of human capital. In a nutshell, Polacheck (1981) extends the basic human capital theory using a hedonic price approach to incorporate occupational choice in order to make predictions about the occupational distribution (occupational segregation). Polacheck argues that women would purposefully choose those occupations with the smallest loss of human capital during periods of out of the labor market career interruptions. Gorlich and de Grip (2009) look at occupational depreciation rates by type of occupation (female, male and integrated) and by skill level (low skilled, high skilled) in Germany. The study takes into account the penalty in the short run and in the long run for maternal leave. The authors find evidence supporting Polacheck's thesis for the short run depreciation in high skilled occupations suggesting that human capital depreciation rates are lower in female occupations than in male occupations. This result does not hold for low-skilled occupations however, suggesting that gender roles may explain segregation in low skilled occupations between men and women. England (1982), Corcoran et al. (1984) and Blau and Ferber (1991) argued that career interruptions are not responsible for occupational segregation. Even if women

\footnotetext{
${ }^{1}$ http://data.consilium.europa.eu/doc/document/ST-14624-2017-ADD-2/en/pdf

2 See Table A1 and Graph A1 measuring occupational segregation in EU countries using the Duncan Index of dissimilarity and proportion females by occupation.
} 
seek jobs that require less training, that is not a reason to expect them to cluster in a particular group of occupations since many male occupations also require less training or skills. Furthermore, women's rates of depreciation and wage growth are similar in female and male dominated occupations. Human capital variables refer to education and experience like job tenure. These variables are included in the models tested. Moreover, we control for part-time in the models since a large part of women have part-time employment in order to be able to combine work with raising children.

Others have investigated the gender pay gap between occupations from a discrimination perspective. Discrimination can arise from: 1) prejudice, 2) market power (monopsonies or trade unions), and 3) imperfect information. All these are obstacles to perfect competition. The presence of discrimination can be linked to: a) an aversion felt by employer towards a certain group (Becker, 1957), b) the unobservability of individual characteristics which can provoke discriminatory firm's behavior (Arrow, 1973; Phelps 1972), or c) the use of supplementary information or beliefs on the average quality of a demographic group or another. The effects of discrimination can accumulate over the life cycle model. It can occur in training, promotion, or pre-market conditions such as schooling and occupational choice. Traditionally, engineering, physics, the judiciary, law and health service administration are considered "male" jobs and library work, nursing and teaching (especially in primary education) are considered "female" jobs (ILO, 2004). There is evidence showing that women who choose non-traditional jobs can face special constraints in the workplace, not least of which are isolation, limited access to mentoring and sexual harassment (ILO, 2004). The study of discrimination has been based on using Blinder-Oaxaca decompositions of the wage into an explained part and an unexplained part. For a recent decomposition of the gender pay gap into an explained part and an unexplained part using the Blinder-Oaxaca decomposition on Structure of Earnings data see Boll and Lagemann (2018: 22).

Occupations differ in many aspects from one another such as: the education and training required, the pleasantness or disagreeability of the work, the status and prestige in which the occupation is held, the probability of success in that line of work and the level of wages in the occupation. Occupational gender pay differentials could be a result of a compensating wage mechanism. According to this theory, women prefer occupations with good working conditions and therefore receive less compensating wage premiums, or they prefer jobs with good fringe benefits and therefore receive less pay. This theory makes several predictions: a) the size of the compensating wage differential for a particular occupation depends on the strength of demand for that occupation, b) the productivity of every job is an increasing and concave function of effort and wages increase with effort, therefore perfect competition ensures that these differences in difficulty of work will be compensated for by wage differentials, c) a competitive market should generate a trade-off between the amount of wages and benefits received by workers of equal productivity if the total dollar value of compensation per hour is to be equal. More recently, Goldin (2014), using a compensating wages theoretical model, and the $\mathrm{O} * \mathrm{Net}$ database on occupational characteristics coupled with information from Census for the USA have highlighted the linearity of the wage schedule with respect to hours worked as a measure of familyfriendly professions. Goldin (2014) argues that the gender pay gap would entirely 
vanish if firms did not have an incentive to disproportionately reward individuals who labored long hours and worked particular hours and if they would enhance temporal flexibility. She argues that some workers want the amenity of flexibility or of lower hours and some firms may find it cheaper to provide. Looking at top earning occupations, she demonstrates that some occupations have high penalties for even small amounts of time out of the labor force and have nonlinear earnings with respect to hours worked, while other occupations, however, have small penalties for time out and almost linear earnings with respect to hours worked. She argues that this is due to information costs and the easiness of substituting workers one for the other.

McPherson and Hirsch (1995) and Baker and Fortin (2001) incorporate in their models controls for occupational physical demands, strength physical demands and environmental hazards in order to control for compensating wage differentials. When McPherson and Hirsch (1995) control for job characteristics, they obtain a substantial reduction in the wage penalty for female jobs in the US and they interpret this as evidence that the relationship between occupational segregation and wages is weak and driven by other job characteristics and differences in the unobserved skills of workers in female and male jobs. Baker and Fortin (2001) replicate and improve on their study, finding even stronger results for Canada. When they control for occupational characteristics, the penalties for female work are driven to zero.

To control for compensating wage differentials we introduce occupational dummies in the models that capture all the occupational characteristics.

Another market based explanation views gender differentials as a result of noncompensating wage differentials that serve to reflect the changing conditions in the economy. If labor is scarce in particular occupation, then this should be reflected in a higher wage rate, whilst abundance of labor will drive the wages down. If the skills required for a particular occupation can be acquired quickly and easily then the supply of labor will be abundant. Low wages reflect therefore the abundance of supply relative to demand for this particular occupation. Non-compensating wage differentials should disappear if labor is sufficiently mobile between occupations. Occupational mobility is difficult to achieve due to: the fact that it takes time to acquire new skills and qualifications, many professions have entry barriers, and some workers may not have the necessary ability to acquire the qualifications for a certain profession. If there are barriers impeding the movement of labor between men's' and women's' jobs, then the labor market is effectively divided into two sections. Wage differentials cannot perform their allocative function redistributing labor between occupations. Men's' higher earnings will persist if their occupation is one in which women find it difficult to move to.

Bergmann's (1974) crowding model is based on the assumption that employers discriminate against women by excluding them from occupations considered men's work. This model does not assume discrimination against the individual but rather against certain types of occupations. The model predicts that wage discrimination is rather across occupations and industries (Boeri, Van Ours, 2013: 105). Given that the demand is limited in "male" occupations, women are crowded in "female" occupations, thereby increasing the supply and reducing their wage. If women are not allowed to enter certain occupations, they will crowd in other occupations driving the wages down 
(Boeri, Van Ours, 2013: 105). The barriers to enter certain occupations may come from unions, customs or self-selection (Boeri, Van Ours, 2013: 105). This model predicts that those doing women's' work earn less than those doing men's' work, despite similar education qualifications, as a result of occupational segregation.

The result of occupational segregation is that the women dominated occupations are overcrowded, in the sense that the marginal productivity of labor is lower in that occupation and the total output could be increased by lowering employment in the female dominated occupations and shifting some labor to the other occupation (Bergmann, 1975).

Crowding may occur because individuals prefer a particular occupation as utility maximizers or because employers behave in a way that excludes individuals from a certain type of occupation (Solberg, Laughlin, 1995). If this hypothesis is true, there should be a gap across occupations but no gap within occupations (Solberg, Laughlin, 1995). There is both a gap across occupations which we look at and within occupations due to glass ceiling.

This hypothesis has been tested by incorporating the proportion of female in human capital earnings reduced form equation. Two levels of analysis have been used: occupational wage models or individual wage models (Sorensen, 1990). Other tests for this hypothesis had relied on occupational switchers using panel data models, however occupational changes in household panels are often spurious and there is a significant measurement bias which can hide effects. Contrary to previous work which assumed the effect to be linear, we hypothesize that the effect is in fact non-linear and we introduce the percentage women square in the models.

The seventh theory is the devaluation theory which argues that wage inequality is socially constructed and work in female-dominated occupations is undervalued as a result of institutionalized bias against women (Perales, 2013). Devaluation theory argues that work in female-dominated occupations is undervalued: "the higher the percentage of females in an occupation, the less the job pays" (England, 1992: 125 cited in Magnusson, 2013). In other words, women's' jobs require similar skills to males' jobs, but they are undervalued. The comparable worth literature suggests the devaluation of caring and nurturing skills traditionally associated with women (Perales, 2010). This institutionalized bias against women leads to wages being lower in women occupations as a result (England, 1992 cited in Perales, 2010). Magnusson (2013) tests the devaluation theory using the Swedish register data and finds that men and women wages are the highest in integrated occupations; she also finds a nonlinear effect of the occupational segregation on the wages. The author also studies the wage payoffs of people moving across occupations with varying sex compositions and finds that both sexes gain by moving to relatively sex-integrated occupations (about 25 to 54\% female).

The role of trade unions on the wage structure and gender pay gap is well researched in the literature. Card et al.(2020) find that there has been a rise in the share of women among the unionized workers and that currently half of the unionized workers in North America are women. Moreover, the authors find that once they disaggregate by sector, the effect of unions on male and female inequality no longer differs, and that the key 
difference in union impacts are between the public and the private sector, not between males and females. Card et al. (2020) state that historically, both in the USA and Canada, union jobs were held largely by unskilled or semi-skilled men working in sectors such as manufacturing, transportation, construction, forestry and mining, but that changed with the steady decline in private sector unionization and rising union influence in the public sector, union coverage rates are now five times higher in the public sector. Moreover this changed the profile of the union worker being a female teacher or nurse with a university degree than a male factory worker with only a high school education (Card et al. 2020). The authors argue that a consistent finding in Canada, the US and the UK is that unions tend to reduce wage inequality among men but not among women. Therefore, we add as controls in the wage regressions on gender pay gap trade union coverage.

\section{The Econometric Model}

The main aim of this paper is to estimate the relationship between the fraction of men and women in a job and the wage controlling for differences between occupations. As far as skills determine wages, there could be occupations in which typical male skills are needed. This will be due to self-selection the occupations with low fractions of women. On the other side of the spectrum there will be occupation with many women in which female skills are required. Other jobs will require skills that can be acquired by both men and women. To capture these three relevant segments in the comparison of occupations, we apply a quadratic term when including the fraction of women in a job.

Drawing on human capital theory and compensating wage differentials, we include both individual and occupational characteristics in our model of wages. However, contrary to previous attempts which try to distinguish between types of occupational hazards and physical strength, our approach relies on cross-country variation. The assumption made to ensure identification is that at the same moment in time the characteristics that cause women to enter occupations are the same in every country. Therefore, we implicitly assume that European countries are similar in terms of technological advances and tools used in an occupation, in other words, that being a nurse in the Czech Republic is going to be as difficult as being a nurse in Sweden. Further, we assume that wages have different starting levels across countries as some countries are wealthier than others. We also assume that the relative position of occupational wages in the occupational structure is the same across European countries, in other words, that nurses earn $22 \%$ less compared to computer professionals in every European country. These assumptions are verified by the data at hand as can be seen from Graph A1 in the Appendix.

Wages in an occupation can be seen as being dependent on both observable and unobservable (to the econometrist) characteristics as follows: 


$$
\begin{aligned}
& \ln W_{o f}=\alpha_{o f}+\sum \beta_{k f} x_{o k f}+\delta F E M_{o f}+\phi F E M_{o f}^{2}+\sum \lambda C N T R Y_{o f}+\sum \tau O C C_{o f}+e_{o f} \\
& \ln W_{o m}=\alpha_{o m}+\sum \beta_{k m} x_{o k m}+\delta F E M_{o m}+\phi F E M_{o m}^{2}+\sum \lambda C N T R Y_{o m}+\sum \tau O C C_{o m}+e_{o m} \\
& \ln \left(W_{o f} / W_{o m}\right)=\alpha_{o g}+\sum \beta_{k g} x_{o k g}+\delta F E M_{o g}+\phi F E M_{o g}^{2}+\sum \lambda C N T R Y_{o g}+\sum \tau O C C_{o g}+e_{o m}
\end{aligned}
$$

where:

- Wo are the wages in profession $\mathrm{O}$ of gender $\mathrm{j}$,

- $\alpha O$ is a constant,

- Xo are workers average observable characteristics in occupation $O$, such as average experience required in an occupation proxied by age, average education, tenure, density of union coverage, average part-time work in an occupation,

- $\beta$ o are prices related to the remuneration of (observable) characteristics for gender $j$ in occupation O. Prices can be time specific or not, gender specific or not,

- FEMo is the ratio of female total employment in the workers occupation,

- $\delta \mathrm{o}$ is the price related to remuneration of the composition of females in occupation $\mathrm{O}$,

- CNTRYo are country dummies,

- OCCo are occupational dummies which cover occupational characteristics such as hazards and characteristics of tasks such as physical strength,

- eo are errors, including the effects of all unobservable characteristics of Occupation O on wages.

Since the precision of our wage data depends on the size of occupational cells, we use a weighted least squares approach in our estimations. The weighting yields more precise coefficient estimates as equally weighting would place a higher weight on very small occupations and too little weight on large occupations for that gender.

The weighted least-squares estimator for the regression of yoi on xoi with the weights woi is given by:

$$
\hat{\beta}_{w}=\left(\sum_{i=1}^{N} w_{i} x_{i} x_{i}^{\prime}\right)^{-1} \sum_{i=1}^{N} w_{i} x_{i} y_{i}
$$

We weight female wages by the number of women in an occupation and male wages by the number of men in an occupation using analytical weights ${ }^{1}$. Occupational gender pay gaps are weighted by the total number of workers in that occupation. Weighting the grouped data by the occupational size, we obtain similar coefficients to individual level regressions (Angrist, Pischke, 2008: 66).

1 We also tried specifications using total occupational sizes but the results did not differ significantly when changing the weight. 


\section{The ESES Data}

We use the European Structure of Earnings Survey (ESES) ${ }^{1}$ data for 2006. This is a comparative matched employer-employee survey carried on by national member states of the European Union. The data collection follows a common methodology which makes the comparative dimension very appealing, especially the common denomination of occupations that follows ISCO 88 classification.

The common methodology employed by the European Structure of Earnings makes international comparisons easier. The information is collected from the management of the establishments which makes it highly reliable. The information for the following countries is available for detailed 3 digits occupational level: Czech Republic, Hungary, Poland, Slovakia, Lithuania, Latvia, Spain, France, Norway and Sweden. The data has the following strengths: large sample sizes (the smallest sample is 83884 observations for Lithuania, the largest is Czech Republic 624031 observations), comparable methodology useful for international comparisons, detailed information about wage components and establishments, and high reliability.

There are two truncations in ESES data: the firm sizes smaller than 10 are missing (for France, Italy, Portugal and Sweden). The second truncation is the missing data on L sector of public administration and compulsory social security contributions (for Spain, France, Italy, Portugal, Norway). The first truncation on small firms could have an impact for the estimates of some countries, particularly if more women are sorting into small firms. Schmitt and Lane (2009) provide an indication of the importance of small firms across European countries. This truncation is expected to be important especially for firms from Italy, Spain and Portugal. Evidence from the European Community Household Panel seems to suggest that this would bias downward the estimate of gender pay gap for these countries (Dupuy et al., 2009). The second truncation on public administration sector could bias the estimates upwards. This is because those jobs are predominantly occupied by women and the gender pay gap is smaller in the public sector as wages are fixed for positions. In 2006, in Hungary, this sector represented $26 \%$ of employees and for Czech Republic, this sector was about $13 \%$, for Lithuania 8\%, Poland 7\%, and Slovakia 7\%. We would expect that the effect would be quite big in Hungary as a large part of the population is employed in public administration. However, for analytical purposes, excluding the public administration jobs should not matter that much as we still have information about public sector jobs such as nurses, doctors or teachers.

The data has been aggregated at ISCO level 3 digits level and represents occupational averages. The unit of analysis is the profession. We use aggregated data as we are not able to control for individual heterogeneity since we only have a cross-section available for 2006. Therefore, to diminish the importance of individual heterogeneity, we use aggregated data. The data retrieved occupational averages by gender and it offers a picture of European Union professions.

${ }^{1}$ Data access has been provided by EUROSTAT within its premises. 
96 The impact of occupational segregation on occupational gender pay GAP in the EU

Table 1: Descriptive Statistics

\begin{tabular}{|l|c|c|c|c|}
\hline & Men & Women & T test & P value \\
\hline Logarithm of average wage & 1.87 & 1.71 & -25.03 & 0.00 \\
\hline Average employment in an occupation & 1709 & 1948 & & \\
\hline Age & 31 & 32 & 7.44 & 0.00 \\
\hline ISCED 0-1 & .057 & .057 & -2.27 & 0.02 \\
\hline ISCED 2 & .140 & .153 & -5.94 & 0.00 \\
\hline ISCED 3-4 & .479 & .451 & 5.64 & 0.00 \\
\hline ISCED 5-6 & .322 & .338 & -0.02 & 0.97 \\
\hline Tenure & 7.02 & 7.39 & 6.07 & 0.00 \\
\hline National agreement coverage & .015 & .019 & -3.03 & 0.00 \\
\hline Industry agreements coverage & .209 & .211 & -3.27 & 0.00 \\
\hline Individual agreements coverage & .046 & .046 & 0.92 & 0.35 \\
\hline Enterprise agreements coverage & .284 & .287 & -1.01 & 0.31 \\
\hline Local agreements coverage & .002 & .003 & -0.73 & 0.46 \\
\hline Other agreements coverage & .014 & .011 & 2.55 & 0.01 \\
\hline No agreements coverage & .321 & .316 & 3.46 & 0.00 \\
\hline Average Part-time & .07 & .15 & 18.28 & 0.00 \\
\hline Average Private sector & .74 & .70 & 6.61 & 0.00 \\
\hline Average Fixed contract & .127 & .134 & -1.33 & 0.18 \\
\hline $\begin{array}{l}\text { Average actual Hours worked without } \\
\text { overtime }\end{array}$ & 163 & 159 & 14.57 & 0.00 \\
\hline $\begin{array}{l}\text { Average actual Hours worked including } \\
\text { overtime }\end{array}$ & 166 & 161 & 16.81 & 0.00 \\
\hline Average Firm size 10-49 & .266 & .233 & 7.00 & 0.00 \\
\hline Average Firm size 50-249 & .296 & .288 & 1.97 & 0.04 \\
\hline Average Firm size 250-449 & .103 & .109 & -2.45 & 0.01 \\
\hline Average Firm size 500-999 & .097 & .105 & -3.44 & 0.00 \\
\hline Average Firm size >1000 & .4235 & .264 & -5.86 & 0.00 \\
\hline Average Percent women in employment & 889 & .465 & & \\
\hline N sample & 837 & & \\
\hline
\end{tabular}

Source: occupational averages calculated from ESES 2006 data

Table 1 provides descriptive statistics of the data used in the analysis. Wages are deflated by the exchange rate and transformed into Euros. They represent average hourly wages without overtime and shift work bonuses. Overall men earn significantly more than women do and this difference is statistically significant. On average, women are one year older than men across occupations. The average employment of women in an occupation seems to be higher than the average employment of men, which could also be due to the fact that women are employed in fewer occupations compared to men. Men have a higher human capital for ISCED level 3-4 compared to women, however for ISCED level 5-6 this difference is not statistically significant. Contrary to expectations, the average tenure of women in an occupation is higher than the men's' tenure over the European Union countries investigated. There are slightly more women covered by national agreements, by industrial agreements and by other agreements. 
There is no statically significant difference between men and women covered by enterprise agreements and individual agreements. On average, there are more men not covered by union agreements than women. Women tend to work more in part-time jobs than men and because the part-timers are counted in the average hours worked, women work on average fewer hours than men. When overtime is included, we see that men also tend to work more hours overtime than women. Men tend to be overrepresented in smaller firm sizes compared to women and women tend to be overrepresented in larger firm sizes. We further try to see whether these associations hold by looking at the variation by proportion female within occupations.

Table 2 provides the means of variables by gender and occupational composition. As we can see, on average, women earn less than men across occupation types except in women dominated professions when, on average, they earn more. Averages can hide important information, therefore we also provide evidence from kernel densities plots which show the distribution of wages. As seen in graph 1-4 Panel A, women have on average lower starting wages in both male and female dominated professions compared to men. Despite the fact that women have higher modal wages in mixed occupations, across the distribution more men earn higher wages compared to women in this type of professions. In female dominated professions, the difference between men and women is predominant at the tails of the distribution and not so much at the average. This means that in female dominated professions women earn a lower starting wage compared to men and they earn a lower top wage compared to men. The differences between men and women remain consistent even when bonuses for shift work and overtime bonuses are taken into account (See Panel B graph 1-4). This suggests that glass ceilings and floor effects cannot be accounted for by access to fringe benefits. Therefore, this evidence does not offer support for the hypothesis that women have lower wages which are compensated for by access to fringe benefits. However, one must note that not all the fringe benefits are present in the ESES data, but the ones that are present are valuable as very few datasets collect information about the amount of fringe benefits.

Going back to Table 2, we see that male dominated professions seem to require a lower level of educational attainment as the two highest frequencies are ISCED level of education 2 and ISCED level of education 3-4. Mixed and female dominated professions seem to require quite a high level of education, as more than $50 \%$ of men and women have ISCED level 3-4 or above. On average, women have a higher tenure than men and interestingly mixed occupations have a lower tenure compared to female and male dominated professions. There is a higher proportion of non-coverage by unions in female dominated professions and the lowest non-coverage is in male dominated professions. The pattern of union density coverage looks quite similar for men and women. Therefore, it seems that trade union power benefits more male dominated professions than female dominated ones. Across professions, women take up more part-time employment compared to men suggesting that household responsibilities are not equally shared. The incidence of part-time is higher particularly in female dominated professions and in mixed professions. Not surprisingly, male dominated professions are more in the private sector whereas female dominated ones are more in the public sector. We see however a difference between men and women as 
less women work in the private sector across professions compared to men. Even for female dominated professions, around $55 \%$ of men are in the private sector compared to $48 \%$ of women. In terms of working hours, male dominated professions require more hours of work compared to mixed occupations and the lowest hours of work are in female dominated professions. Men work on average more hours and do more overtime hours compared to women across types of professions except in female professions where overtime hours is on average 2 hours for each gender.

Table 2: Means of selected variables by Gender composition

\begin{tabular}{|c|c|c|c|c|c|}
\hline \multirow[b]{2}{*}{ Variable } & \multirow[b]{2}{*}{$0-.25$} & \multicolumn{3}{|c|}{ Value of proportion female } & \multirow[b]{2}{*}{$\overline{\text { All }}$} \\
\hline & & $.25-.50$ & $.50-.75$ & $.75-1.0$ & \\
\hline \multicolumn{6}{|l|}{ Means for women } \\
\hline Logarithm of average wage & 1.84 & 1.78 & 1.73 & 1.43 & 1.71 \\
\hline Average employment in an occupation & 386 & 1032 & 2338 & 4734 & 1948 \\
\hline Age & 32 & 32 & 32 & 32 & 32 \\
\hline ISCED 0-1 & .097 & .064 & .034 & .019 & .057 \\
\hline ISCED 2 & .235 & .162 & .109 & .080 & .153 \\
\hline ISCED 3-4 & .472 & .417 & .386 & .541 & .451 \\
\hline ISCED 5-6 & .194 & .356 & .469 & .358 & .338 \\
\hline Tenure & 7.55 & 7.24 & 6.90 & 7.94 & 7.39 \\
\hline National agreement coverage & .010 & .013 & .023 & .033 & .019 \\
\hline Industry agreements coverage & .246 & .239 & .202 & .138 & .211 \\
\hline Individual agreements coverage & .066 & .045 & .046 & .022 & .046 \\
\hline Enterprise agreements coverage & .309 & .286 & .260 & .292 & .287 \\
\hline Local agreements coverage & .003 & .004 & .003 & .002 & .003 \\
\hline Other agreements coverage & .009 & .008 & .016 & .012 & .011 \\
\hline No agreements coverage & .211 & .328 & .358 & .401 & .316 \\
\hline Average Part-time & .110 & .137 & .180 & .178 & .15 \\
\hline Average Private sector & .824 & .768 & .679 & .489 & .70 \\
\hline Average Fixed contract & .138 & .139 & .139 & .116 & .134 \\
\hline Average actual Hours worked without overtime & 161 & 159 & 157 & 156 & 159 \\
\hline $\begin{array}{l}\text { Average actual Hours worked including } \\
\text { overtime }\end{array}$ & 164 & 161 & 159 & 158 & 161 \\
\hline Average Firm size 10-49 & .192 & .239 & .255 & .254 & .233 \\
\hline Average Firm size 50-249 & .274 & .283 & .295 & .303 & .288 \\
\hline Average Firm size 250-449 & .129 & .112 & .099 & .089 & .109 \\
\hline Average Firm size 500-999 & .127 & .110 & .093 & .083 & .105 \\
\hline Average Firm size $>1000$ & .275 & .254 & .255 & .269 & .264 \\
\hline N sample & 245 & 205 & 212 & 175 & 837 \\
\hline \multicolumn{6}{|l|}{ Means for men } \\
\hline Logarithm of average wage & 2.00 & 1.90 & 1.84 & 1.55 & 1.87 \\
\hline Average employment in an occupation & 2469 & 1684 & 1330 & 754 & 1709 \\
\hline Age & 32 & 32 & 31 & 31 & 31 \\
\hline ISCED 0-1 & .090 & .055 & .037 & .022 & .057 \\
\hline ISCED 2 & .203 & .139 & .098 & .075 & .140 \\
\hline ISCED 3-4 & .542 & .461 & .392 & .498 & .479 \\
\hline ISCED 5-6 & .163 & .344 & .471 & .404 & .322 \\
\hline Tenure & 7.71 & 6.98 & 6.60 & 6.26 & 7.02 \\
\hline National agreement coverage & .004 & .010 & .021 & .033 & .015 \\
\hline
\end{tabular}




\begin{tabular}{|l|c|c|c|c|c|}
\hline \multicolumn{1}{|c|}{ Variable } & \multicolumn{2}{c|}{ Value of proportion female } & \\
\hline \multicolumn{1}{|c|}{} & $\mathbf{0 - . 2 5}$ & $. \mathbf{2 5}-\mathbf{. 5 0}$ & $\mathbf{. 5 0 - . 7 5}$ & $\mathbf{. 7 5 - 1 . 0}$ & All \\
\hline Industry agreements coverage & .245 & .224 & .191 & .141 & .209 \\
\hline Individual agreements coverage & .058 & .050 & .043 & .022 & .046 \\
\hline Enterprise agreements coverage & .295 & .283 & .267 & .288 & .284 \\
\hline Local agreements coverage & .003 & .002 & .003 & .001 & .002 \\
\hline Other agreements coverage & .011 & .012 & .019 & .014 & .014 \\
\hline No agreements coverage & .241 & .342 & .363 & .396 & .321 \\
\hline Average Part-time & .033 & .069 & .102 & .124 & .07 \\
\hline Average Private sector & .849 & .792 & .695 & .555 & .74 \\
\hline Average Fixed contract & .111 & .129 & .132 & .149 & .127 \\
\hline Average actual Hours worked without overtime & 166 & 163 & 161 & 158 & 163 \\
\hline Average actual Hours worked including overtime & 170 & 166 & 163 & 160 & 166 \\
\hline Average Firm size 10-49 & .274 & .281 & .263 & .237 & .266 \\
\hline Average Firm size 50-249 & .292 & .294 & .3026 & .300 & .296 \\
\hline Average Firm size 250-449 & .110 & .107 & .095 & .092 & .103 \\
\hline Average Firm size 500-999 & .107 & .096 & .090 & .092 & .097 \\
\hline Average Firm size >1000 & .214 & .219 & .249 & .277 & .235 \\
\hline N sample & 313 & 205 & 212 & 159 & 889 \\
\hline
\end{tabular}

Source: occupational averages calculated from ESES 2006 data

\section{PANEL A: AVERAGE OCCUPATIONAL WAGES CENTERED AT THE COUNTRY MEAN}

Graph 1. Kernel densities for Men and Women wages in male dominated occupations

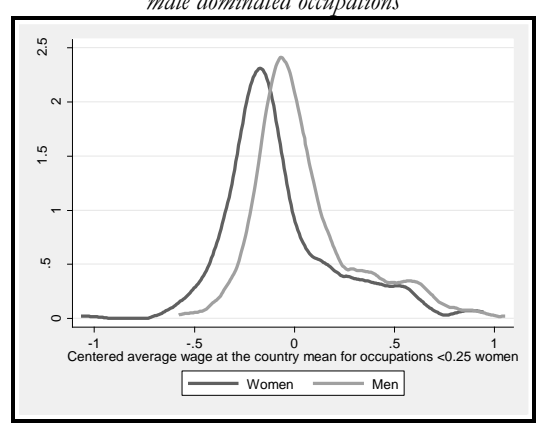

Graph 3. Kernel densities in mixed occupations

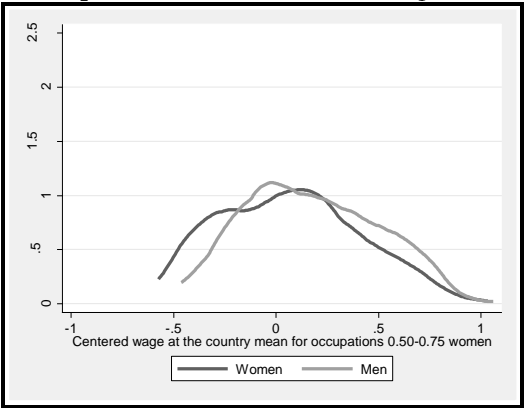

Graph 2. Kernel densities for Men and Women wages in

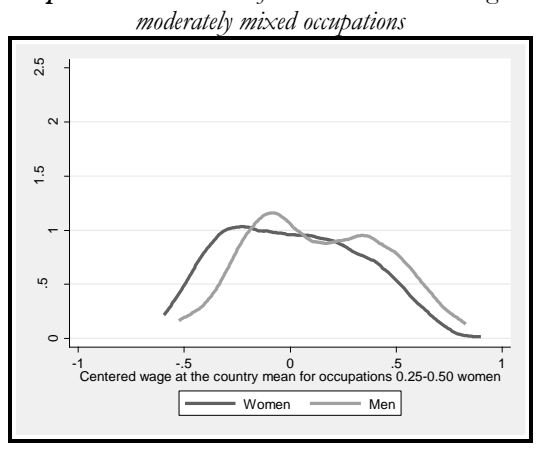

Graph 4. Kernel densities in female dominated occupations

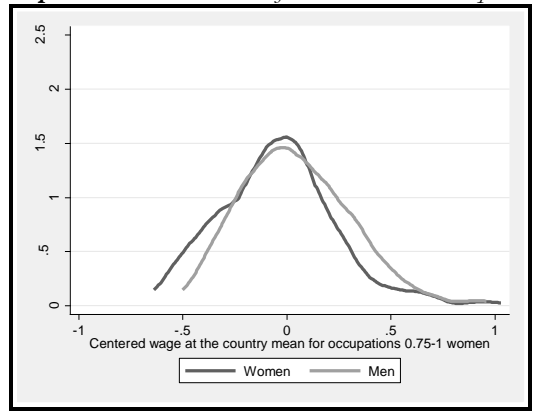




\section{PANEL B: AVERAGE TOTAL OCCUPATIONAL WAGES INCLUDING OVERTIME AND SHIFT WORK BONUSES CENTERED AT THE COUNTRY}

MEAN

Graph 1. Kernel densities for Men and Women wages in male dominated occupations

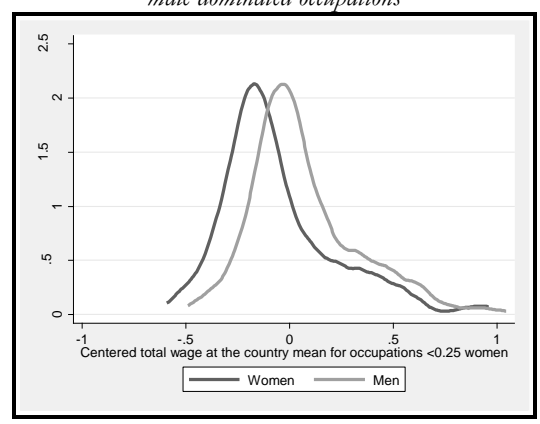

Graph 3. Kernel densities in mixed occupations

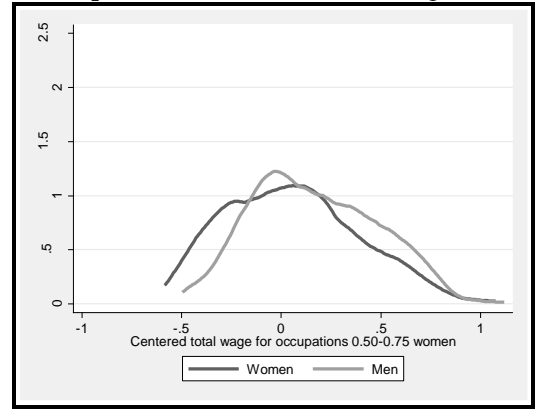

Graph 2. Kernel densities for Men and Women wages in moderately mixed occupations

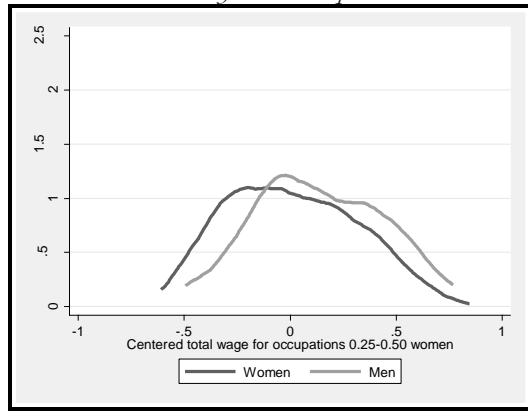

Graph 4. Kernel densities in female dominated occupations

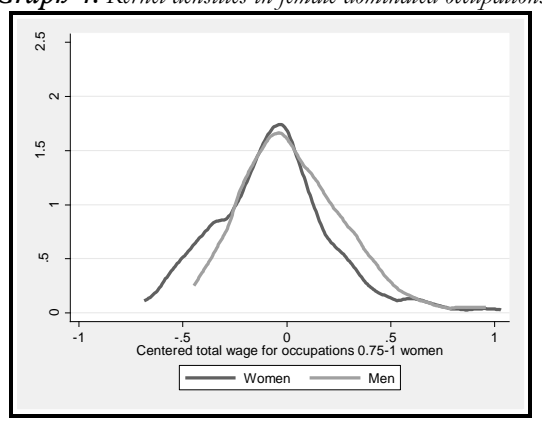

\section{Estimation Results}

We have three wage measures: female occupational average wages, male occupational average wages and the occupational gender pay gap which is a logarithmic ratio of female wages divided by male wages.

Table 3F presents the estimates for the female wages and 3M for the male wages. The quadratic patterns are depicted in Panel C. In the models in which we do not control for occupational or individual characteristics, wages for males and females are highest in mixed occupations, with men earning more than women (See Panel C Graph 1 and 1, Panel E Graph 9 and 10). The question this results leads to is whether the characteristics of these occupations or the act that employ both men and women explain the higher wages. To disentangle effects of characteristics of the occupation and the fraction women we include occupational dummies to the specification. The nonlinear relationship between percentage of female and male occupational wages becomes inverted (See Panel C Graph 1 and Graph 2), with mixed occupations having lower wages for men, and female occupations having lower wages for women (See table $3 \mathrm{~F}$ and $3 \mathrm{M}$ ). This therefore implies that indeed the character of the occupation and not the gender ratio accounted for these high wages. A potential explanation is that 
occupations that require a lot of education can be occupied by both men and women because these skills acquired at school are less gender specific. When occupational dummies are added as controls, we see that female wages are lower than male wages across the distribution, the gender pay gap being larger in female occupations. There can be several explanations for these differences. First, part of these differences could be caused by human capital investment differences between men and women. We measure human capital as educational investment and experience, proxied by age and tenure. When we control for human capital investment, the effect of proportion female on female and male wages becomes rather similar in magnitude (Table 3F and Table $3 \mathrm{M}$ Model 2), however differences between men and women are quite wide for female dominated occupations (Panel C Graph 2 and 3). Controlling for human capital, men earn less than in male dominated occupations but significantly more than in mixed occupations (Panel C Graph 3). Controlling for human capital, women earn less than women working in mixed or male dominated occupations (Panel C Graph 3). A second explanation is part-time work. When we control for the percent of women in part-time work and the percent of men in part-time work, we see that the penalty for the feminization of an occupation becomes larger for women and slightly larger for men suggesting that part time is well paid (Table 3F and 3M Model 3). Controlling for parttime, women's returns in male occupations seem to be higher than those of men, but the opposite is true for female dominated professions (Panel C Graph 4). A third explanation could be trade unions. When we control for the percent of women covered by bargaining agreements we see that trade union coverage increases the returns for occupations across the distribution, and particularly women in female occupations seem to be earning more now than in mixed occupations (Panel C Graph 5). Adding bargaining controls for men also shifts the returns across occupational types up, suggesting that men covered also earn more (Panel C Graph 5). The bargaining institutions manage to make the differences between men and women working in female occupations smaller in magnitude compared to models which did not include these variables. Once we control for union coverage for both men and women, mixed occupations are the ones with lower returns and the gender pay gap seems to be larger for male or female occupations (Panel C Graph 5). Controlling for the characteristics women earn relatively more in male occupations and men earn relatively more in female occupations. Since the fraction of women in an occupation is on average below 0.5 , this still leads to higher wages for men compared to women on average.

Table 3F: The effect of proportion female on female wages controlling for country and occupational dummies

\begin{tabular}{|l|l|l|l|l|l|}
\hline & \multicolumn{5}{|c|}{ Basic women wages } \\
\hline & \multicolumn{1}{|c|}{ Model 1 } & \multicolumn{1}{|c|}{ Model 2 } & \multicolumn{1}{|c|}{ Model 3 } & \multicolumn{1}{|c|}{ Model 4 } & \multicolumn{1}{c|}{ Model 5 } \\
\hline Percentage women & -0.339 & $-0.438^{* *}$ & $-0.687^{* * *}$ & $-0.693^{* * *}$ & $-0.710^{* * *}$ \\
\hline Sd. Err & $(0.217)$ & $(0.211)$ & $(0.221)$ & $(0.214)$ & $(0.211)$ \\
\hline Percentage women square & 0.100 & 0.251 & $0.406^{* *}$ & $0.474^{* * *}$ & $0.541^{* * *}$ \\
\hline Sd. Err & $(0.169)$ & $(0.164)$ & $(0.168)$ & $(0.163)$ & $(0.161)$ \\
\hline Country dummies & YES & YES & YES & YES & YES \\
\hline Occupation dummies & YES & YES & YES & YES & YES \\
\hline Human capital variables & YES & YES & YES & YES \\
\hline
\end{tabular}


102 The impact of occupational segregation on occupational gender pay GAP in the EU

\begin{tabular}{|l|l|l|l|l|l|}
\hline & \multicolumn{5}{|c|}{ Basic women wages } \\
\hline & \multicolumn{1}{|c|}{ Model 1 } & \multicolumn{1}{|c|}{ Model 2 } & \multicolumn{1}{|c|}{ Model 3 } & Model 4 & \multicolumn{1}{c|}{ Model 5 } \\
\hline Part-time dummy & & & YES & YES & YES \\
\hline Union density dummies & & & YES & YES \\
\hline Occupation size & & & & YES \\
\hline R square & 0.980 & 0.982 & 0.982 & 0.984 & 0.984 \\
\hline N & 771 & 771 & 771 & 771 & 771 \\
\hline $\begin{array}{l}\text { EU 25 Women Labor } \\
\text { Force Participation }\end{array}$ & 57.6 & 57.6 & 57.6 & 57.6 & 57.6 \\
\hline
\end{tabular}

Notes: Reference categories are: Czech Republic, computer professionals, ISCED 5-6 level of education, not covered by bargaining agreements. Human capital variables include: age 40-tenure, tenure, ISCED 0-1, ISCED 2, ISCED 3-4 educational categories. Bargaining coverage includes: national, industry, enterprise, local, individual and other agreements. Occupational dummies are defined at ISCO 3 digits level and per country are 87 occupations observed, completely male and female dominated occupations are excluded. Regressions are weighted by the number of working women in that occupation.

Table 3M: The effect of proportion female on female wages controlling for country and occupational dummies

\begin{tabular}{|l|l|l|l|l|l|}
\hline \multicolumn{7}{|l|}{ Basic male wages } \\
\hline & Model 1 & Model 2 & Model 3 & Model 4 & Model 5 \\
\hline Percentage women & $-0.602^{* * *}$ & $-0.586^{* * *}$ & $-0.630^{* * *}$ & $-0.616^{* * *}$ & $-0.608^{* * *}$ \\
\hline Sd. Err & $(0.121)$ & $(0.115)$ & $(0.116)$ & $(0.115)$ & $(0.115)$ \\
\hline Percentage women square & $0.477^{* * *}$ & $0.512^{* * *}$ & $0.556^{* * *}$ & $0.552^{* * *}$ & $0.539^{* * *}$ \\
\hline Sd. Err & $(0.128)$ & $(0.121)$ & $(0.123)$ & $(0.121)$ & $(0.121)$ \\
\hline Country dummies & YES & YES & YES & YES & YES \\
\hline Occupation dummies & YES & YES & YES & YES & YES \\
\hline Human capital variables & & YES & YES & YES & YES \\
\hline Part-time dummy & & YES & YES & YES \\
\hline Union density dummies & & & YES & YES \\
\hline Occupation size & & & & & YES \\
\hline R square & 0.987 & 0.989 & 0.989 & 0.989 & 0.989 \\
\hline N & 771 & 771 & 771 & 771 & 771 \\
\hline $\begin{array}{l}\text { EU 25 Male Labor Force } \\
\text { Participation }\end{array}$ & 72.1 & 72.1 & 72.1 & 72.1 & 72.1 \\
\hline
\end{tabular}

Notes: Reference categories are: Czech Republic, computer professionals, ISCED 5-6 level of education, not covered by bargaining agreements. Human capital variables include: age 40-tenure, tenure, ISCED 0-1, ISCED 2, ISCED 3-4 educational categories. Bargaining coverage includes: national, industry, enterprise, local, individual and other agreements. Occupational dummies are defined at ISCO 3 digits level and per country are 87 occupations observed, completely male and female dominated occupations are excluded. Regressions are weighted by the number of working men in that occupation. 
PANEL C. THE EFFECT OF OCCUPATIONAL SEGREGATION ON MALE DOMINATED, MIXED AND FEMALE DOMINATED PROFESSIONS UNDER DIFFERENT SPECIFICATIONS

Graph 1. The effect of proportion female on female wages, male wages and gender pay gap without occupational controls

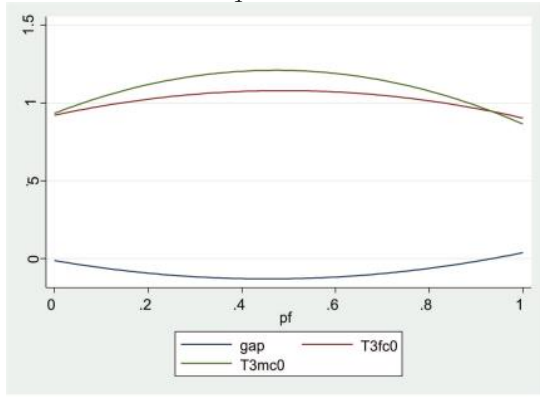

Graph3. The effect of proportion female on female wages, male wages and gender pay gap with occupational and buman capital controls

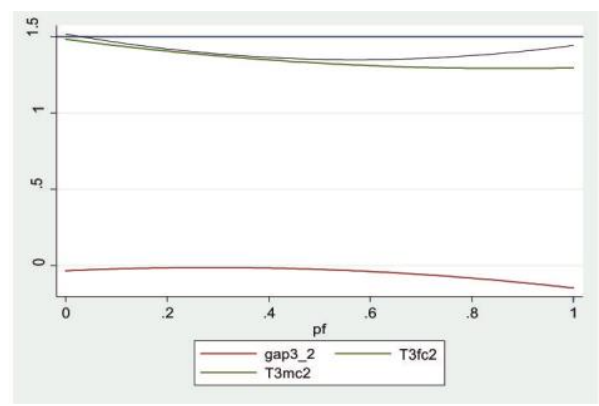

Graph 5. The effect of proportion female on female wages, male wages and gender pay gap with occupational, buman capital, part-time and bargaining coverage controls

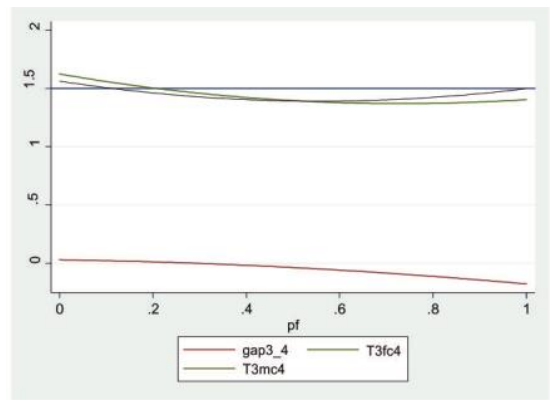

Graph2. The effect of proportion female on female wages, male wages and gender pay gap with occupational controls

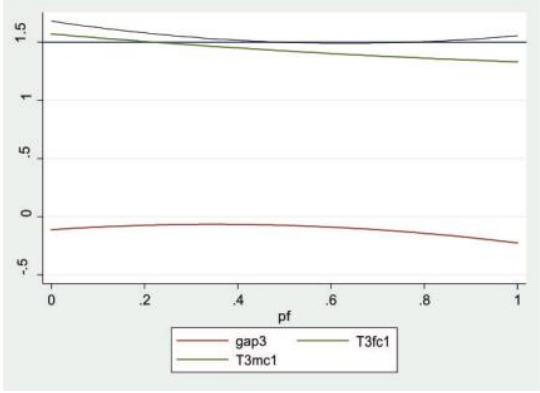

Graph 4. The effect of proportion female on female wages, male wages and gender pay gap with occupational and buman capital and part-time controls

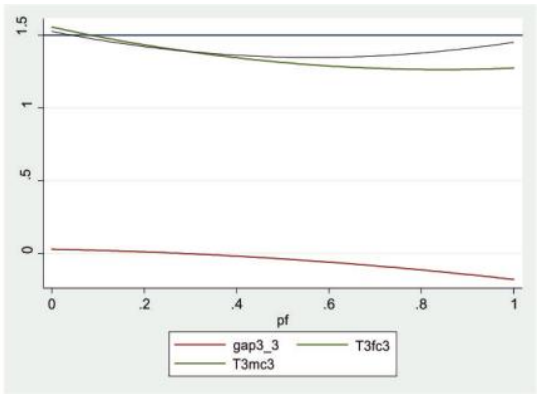

Graph 6. The effect of proportion female on female wages, male wages and gender pay gap with occupational, buman capital, part-time, bargaining coverage and occupational size controls

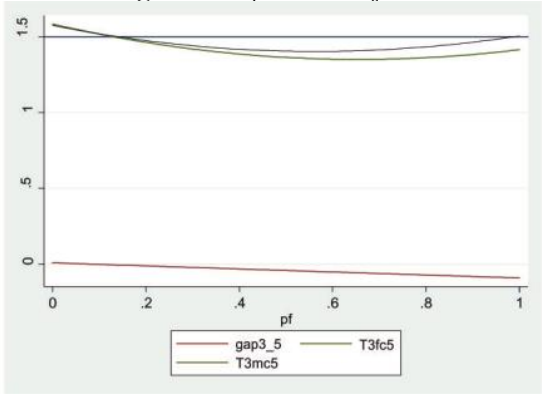


104 The impact of occupational segregation on occupational gender pay GAP in the EU

In Panels $\mathrm{D}$ and $\mathrm{E}$ we present the relationship between the percentage females and the wages of men and women varying the order in which controls are included. This provides support for the hypothesis that the high wages for mixed occupations is due to high investments in education there. If occupational dummies are not included then the strong positive effect of mixed occupations on wages disappears once we control for education.

\section{PANEL D. THE EFFECT OF ADDING VARIABLES ON FEMALE AND MALE WAGES CONTROLLING FOR OCCUPATION AND COUNTRY EFFECTS}

Graph 7. The effect of proportion female on female wages with occupational, human capital, part-time, bargaining coverage and occupational size controls

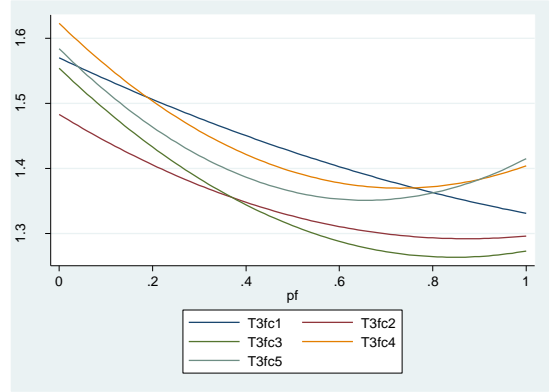

Graph 8. The effect of proportion female on male wages with occupational, human capital, part-time, bargaining coverage and occupational size controls

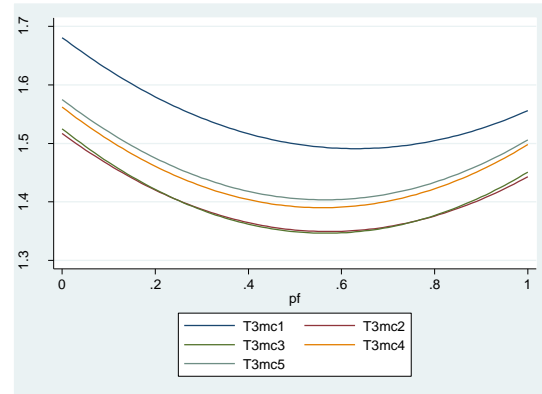

PANEL E. THE EFFECT OF ADDING VARIABLES ON FEMALE AND MALE WAGES CONTROLLING ONLY FOR COUNTRY EFFECTS WITHOUT OCCUPATIONAL DUMMIES CONTROLS

Graph 9. The effect of proportion female on female wages with all other controls except occupational dummies

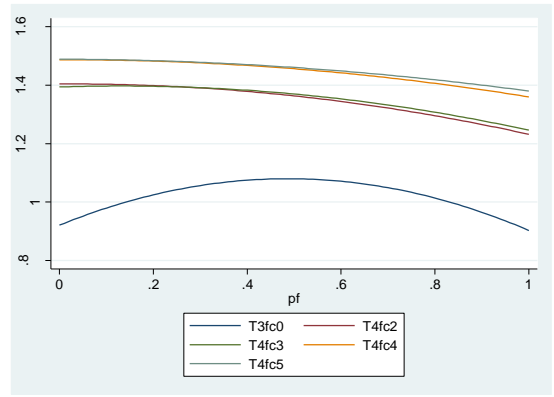

Graph 10. The effect of proportion female on male wages with all other controls except occupational dummies

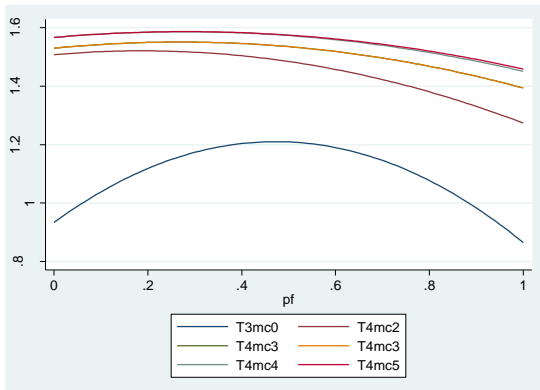

Table 4 provides estimates for the relationship between the gender wage gap and the fraction women in an occupation. Panel F shows the patterns graphically. It shows that the gender pay gap depends substantially on the fraction of women in a job. When few controls are added, women earn less in all occupations, but this difference is larger in female 
occupations. When human capital variables are added, the effect of occupational segregation becomes even larger on the gender pay gap. The more controls are added, the smaller the average gender wage gap, with, in the end, a smaller gender wage gap (women earn slightly less than men) in male occupations and a larger gender wage gap in female occupations.

Table 4: The effect of proportion female on gender pay gap ratio controlling for country and occupational dummies

\begin{tabular}{|c|c|c|c|c|c|}
\hline & \multicolumn{2}{|c|}{ Gap basic wages } & \multirow[b]{2}{*}{ Model 4} & \multirow[b]{2}{*}{ Model 5} & \multirow[b]{2}{*}{ Model 6} \\
\hline & Model 1 & Model 3 & & & \\
\hline Percentage women & $-0.228^{* * *}$ & $-0.234 * * *$ & $-0.249^{* * *}$ & $-0.210^{* *}$ & $-0.205^{* *}$ \\
\hline Sd. Err & $(0.080)$ & $(0.082)$ & $(0.083)$ & $(0.084)$ & $(0.084)$ \\
\hline $\begin{array}{l}\text { Percentage women } \\
\text { square }\end{array}$ & $0.133^{*}$ & $0.123^{*}$ & $0.132 *$ & 0.099 & 0.102 \\
\hline Sd. Err & $(0.071)$ & $(0.073)$ & $(0.074)$ & $(0.075)$ & $(0.075)$ \\
\hline Country dummies & YES & YES & YES & YES & YES \\
\hline Occupation dummies & YES & YES & YES & YES & YES \\
\hline \multicolumn{2}{|l|}{ Human capital variables } & YES & YES & YES & YES \\
\hline \multicolumn{2}{|l|}{ Part-time dummy } & & YES & YES & YES \\
\hline \multicolumn{3}{|l|}{ Union density dummies } & & YES & YES \\
\hline \multicolumn{2}{|l|}{ Occupation size } & & & & YES \\
\hline R square & 0.651 & 0.682 & 0.684 & 0.698 & 0.698 \\
\hline $\mathrm{N}$ & 771 & 771 & 771 & 771 & 771 \\
\hline
\end{tabular}

Note: Reference categories are: Czech Republic, computer professionals, ISCED 5-6 level of education, not covered by bargaining agreements. Human capital variables include: age ratio women to men, age ratio women to men squared, tenure ratio women to men, ISCED 0-1, ISCED 2, ISCED 3-4 educational categories for each gender. Bargaining coverage includes: national, industry, enterprise, local, individual and other agreements for each gender. Occupation size includes the number of women employed in that occupation out of the total women working in the sample, and the number of men employed in that occupation out of the total men working in the sample. Occupational dummies are defined at ISCO 3 digits level and per country are 87 occupations observed. Regressions are weighted by the number of working individuals in that occupation.

\section{PANEL F. THE EFFECT OF ADDING VARIABLES ON THE GENDER PAY GAP CONTROLLING FOR COUNTRY EFFECTS AND OCCUPATIONAL DUMMIES CONTROLS}

Graph 9. The effect of proportion female on gender pay gap with all other controls 


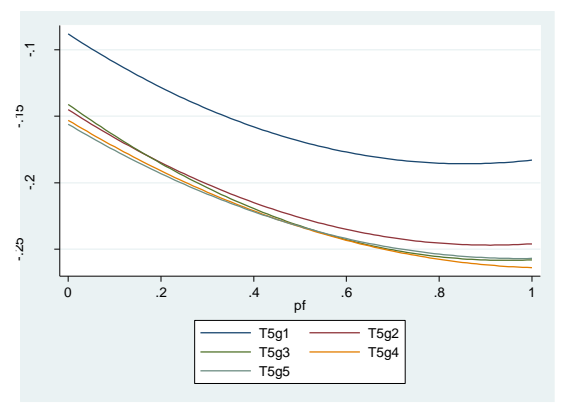

\section{Concluding remarks}

The aim of this paper was to investigate whether the fraction of women in a job has an impact on male and female wages in occupations are therefore if it can account for the gender pay gap. Previous papers suggested that both men and women earn less in female occupations. These studies, however, assumed this relationship to be linear and could account for differences between occupation only by controlling for detailed occupational characteristics. The measurement of these characteristics is limited and shifts the discussion further to the questions whether characteristics for female occupations are paid relatively low. By using data for different countries we are able to estimate the relationship between the fraction of women and wages, including occupational dummies. In that way we are able to estimate the pure effect of the fraction of women in an occupation. By including a quadratic specification we account for potential non-linearities.

We use the European Structure of Earnings data for 2006 to retrieve occupational wages at a detailed three digits level and we use the grouped data in a weighted least square estimation. We assume that the relative position of occupational wages in the occupational structure is the same across European countries and that being employed in a certain occupation implies the same tasks in each country. Based on this assumptions we are able to identify the effect of the proportion female on female and male occupational wages exploring the cross-country variation.

Our results show that the relationship between the proportion of female in an occupation and occupational average wages for men and women is non-linear. Most of the literature emphasizes a negative effect of the composition of wages on male and female wages. However, Perales (2010) finds also a non-linear relationship using the British Household Panel Survey augmented with Labour Force Survey and 2006 Skills Survey. His estimations show an inverted $U$ relationship similar to the one we find when we do not control for occupational characteristics. When we fully control for all occupational characteristics by adding occupational dummies, we show that there is a $U$ relationship between occupational segregation and occupational wages. This finding is new in the literature. Magnusson using Swedish register data (2013) also finds a nonlinear relationship between the percent female in an occupation and wages. She finds the highest wages are earned for both men and women in integrated mixed occupations. 
Further, our results show that - controlling for occupational characteristics - for men the relationship between the fraction of women and wages is U-shaped. Men earn relatively high wages in occupations with either very few or many women. Women follow a similar pattern, but with a slightly downward trend added to this when moving to the female occupations. Adding controls with characteristics like part-time work, education and union coverage, removes this downward trend and leads to U-shaped patterns for both men and women, with men earning relatively high wages in the female occupations and women earning relatively high wages in male occupations. Further research is needed into the shape of the relationship; future research should use panel data at the individual level for several countries with more variables as controls. Given our survey data and research design the current article is limited in its scope.

\section{References}

Angrist, J. D., \& Pischke, J. S. (2008). Mostly harmless econometrics: An empiricist's companion. Princeton University Press.

Arrow, K. J. (1973).The theory of discrimination. In: Ashenfelter, O., \& Rees, A. (Eds.), Discrimination in labour markets (pp. 3-33), Princeton, N.J.: Princeton University Press.

Altonji, J., \& Blank, R. (1999). Race and Gender in the labour market. In: Ashenfelter, O., \& Card, D. (Eds.), Handbook of Labor Economics, Vol. 3, Part C (pp. 3143-3259), Elsevier.

Baker, M., \& Cornelson, K. (2018). Gender-based occupational segregation and sex differences in sensory, motor, and spatial aptitudes. Demography, 55(5), 1749-1775.

Baker, M., \& Fortin, N. M. (2001). Occupational gender composition and wages in Canada, 19871988. Canadian Journal of Economics/Revue canadienne d'économique, 34(2), 345-376.

Becker, G. S. (1957). The economics of discrimination, Chicago, IL: University of Chicago Press.

Bergmann, B. R. (1974). Occupational segregation, wages and profits when employers discriminate by race or sex. Eastern Economic Journal, 1(2), 103-110.

Bettio, F., Verashchagina, A., Mairhuber, I., \& Kanjuo-Mrčela, A. (2009). Gender segregation in the labour market: Root causes, implications and policy responses in the EU. Luxembourg: Publications Office of the European Union (pp. 90-94).

Blinder, A. S. (1973). Wage discrimination: reduced form and structural estimates. Journal of Human Resources, 8(4), 436-455.

Blau, F. D., \& Ferber, M. A. (1991). Career plans and expectations of young women and men: The earnings gap and labor force participation. Journal of Human Resources, 26(4), 581-607.

Blau, F., \& Kahn, L. M. (2017). The Gender Wage Gap: Extent, Trends, and Explanations. Journal of Economic Literature, 55(3), 789-865.

Blau, F. D., \& Kahn, L. M. (1996). International differences in male wage inequality: institutions versus market forces. Journal of Political Economy, 104(4), 791-837.

Blau, F., \& Kahn, L. M. (2003). Understanding International Differences in the Gender Pay Gap. Journal of Labor Economics, 21(1), 106-144.

Boeri, T., \& Van Ours, J. (2013). The economics of imperfect labour markets. Second Edition. Priceton University Press.

Boll, C., \& Lagemann, A. (2018). Gender pay gap in EU countries based on SES (2014). Luxembourg, Publication Office of the European Union.

Brynin, M., \& Perales, F. (2016). Gender wage inequality: The de-gendering of the occupational structure. European Sociological Review, 32(1), 162-174. 
108 The impact of occupational segregation on occupational gender pay GAP in the EU

Burchell, B., Hardy, V., Rubery, J., \& Smith, M. (2014). "A New Method to Understand Occupational Gender Segregation in European Labour Markets". European Commission, Luxembourg, 2014, available at: http://ec.europa.eu/justice/gender-equality/files/ documents/150119_segregation_report_web_en.pdf

Card, D., Lemieux, T., \& Riddell, W. C. (2020). Unions and wage inequality: The roles of gender, skill and public sector employment. Canadian Journal of Economics/Revue canadienne d'économique, 53(1), 140-173.

Council of the European Union, "Gender segregation in education, training and the labour market Review of the implementation of the Beijing Platform for Action in the EU Member States", Report prepared by European Institute for Gender Equality (EIGE) at the request of the Estonian Presidency, 2017, http://data.consilium.europa.eu/ doc/document/ST-14624-2017-ADD-2/en/pdf

Corcoran, M., Duncan, G. J., \& Ponza, M. (1984). Work Experience, Job Segregation, and Wages. In: Reskin, B. F. (Ed.): Sex Segregation in the Workplace: Trends, Explanations, Remedies (pp. 171-179).Washington, D.C.: National Academy Press.

Cotter, D. A., Hermsen, J. M., \& Vanneman, R. (2004). Gender inequality at work. New York: Russell Sage Foundation.

Dupuy, A, Fourage, D., \& Buligescu, B. (2009). Development of econometric methods to evaluate the Gender Pay Gap using the European Structure of Earnings Data. Eurostat methodologies and Working papers, Luxembourg Office for Official Publications of the European Communities.

England, P. (1982). The failure of human capital theory to explain occupational sex segregation. Journal of Human Resources, 18, 358-370.

England, P. (1992). Comparable Worth. Theories and Evidence. New York, NY: Aldine de Gruyter.

European Institute for Gender Equality (EIGE) (2017). Gender segregation in education, training and the labour market. Review of the implementation of the Beijing Platform for Action in the EU Member States. Available at URL: https://data.consilium.europa.eu/ doc/document/ST-14624-2017-ADD-2/en/pdf

Freeman, R. B., \& Oostendorp, R. (2000). Wages around the world: pay across occupations and countries (No. w8058). National Bureau of Economic Research.

Goldin, C. (2014). A grand gender convergence: Its last chapter. American Economic Review, 104(4), 1091-1119.

Goldin, C., Kerr, S. P., Olivetti, C., \& Barth, E. (2017). The expanding gender earnings gap: Evidence from the LEHD-2000 Census. American Economic Review, 107(5), 110-14.

Gorlich, D., \& de Grip, A. (2009). Human capital depreciation during family-related career interruptions in male and female occupations. Oxford Economic Papers, 61, i98-i121.

Gupta, N. D. (1993). Probabilities of job choice and employer selection and male-female occupational differences. The American Economic Review, 83(2), 57-61.

Hook, J. L., \& Pettit, B. (2008). Reproducing occupational inequality: Marriage, parenthood and the gender divide in occupations (No. 481). LIS Working Paper Series.

ILO (2004). World Employment and Social Outlook 2004.

ILO (2018). World Employment and Social Outlook - Trends 2018.

Kim, M. K., \& Polachek, S. W. (1994). Panel estimates of male-female earnings functions. Journal of Human Resources, 29(2), 406-428.

Kunze, A. (2000). The Determination of Wages and the Gender Wage Gap: A Survey. IZA DP, 193, 1-67.

Kunze, A. (2008). Gender wage gap studies: consistency and decomposition. Empirical Economics, $35(1), 63-76$. 
Levanon, A., \& Grusky, D. B. (2016). The persistence of extreme gender segregation in the twenty-first century. American Journal of Sociology, 122(2), 573-619.

Magnusson, C. (2013). More women, lower pay? Occupational sex composition, wages and wage growth. Acta Sociologica, 56(3), 227-245.

Macpherson, D. A., \& Hirsch, B. T. (1995). Wages and gender composition: why do women's jobs pay less?. Journal of Labor Economics, 13(3), 426-471.

Neumark, D., Bayard K., Hellerstein J. K., \& Troske, K. R. (2004). New evidence on sex segregation and sex differences in ages from matched employer-employee data. In: Newmark, D. (Ed.), Sex differences in labor markets (pp. 299-332). Routlege Research in Gender and Society, Routledge.

Oostendorp, R., (2004). Globalization and the gender wage gap. Amsterdam Institute for Development, Mimeo.

Perales, F., (2010). Occupational feminization, Specialized Human Capital and Wages: Evidence from the British Labour Market. ISER Working Paper Series, No. 2010-31, 1-49.

Perales, F. (2013). Occupational sex-segregation, specialized human capital and wages: evidence from Britain. Work, Employment and Society, 27(4), 600-620.

Plasman, R., \& Sissoko, S. (2004). Comparing apples with oranges: Revisiting the gender wage gap in an international perspective. Available at SSRN: https://ssrn.com/abstract $=644322$

Phelps, E. S. (1972). The statistical theory of racism and sexism. The American Economic Review, 62(4), 659-661.

Polachek, S. W. (1981). Occupational self-selection: A human capital approach to sex differences in occupational structure. The review of Economics and Statistics, 63(1), 60-69.

Rosen, S. (1974). Hedonic prices and implicit markets: product differentiation in pure competition. Journal of Political Economy, 82(1), 34-55.

Schmitt, J., \& Lane, N. (2009). An international comparison of small business employment. Washington, DC: Center for Economic and Policy Research.

Solberg, E., \& Laughlin, T. (1995). The gender pay gap, fringe benefits, and occupational crowding. ILR Review, 48(4), 692-708.

Sorensen, E. (1990). The crowding hypothesis and comparable worth. Journal of Human Resources, 25(1), 55-89.

Strawinski, P., Majchrowska, A., \& Broniatowska, P. (2018). Occupational segregation and wage differences: the case of Poland. International Journal of Manpower, 39(3), 378-397. 
110 The impact of occupational segregation on occupational gender pay GAP in the EU

\section{Appendix}

Table A1: Duncan and Duncan (1955) Index of dissimilarity measuring occupational segregation

\begin{tabular}{|c|c|c|c|c|}
\hline & $\begin{array}{c}1997 \\
\text { (occupational) }\end{array}$ & $\begin{array}{c}2007 \\
\text { (occupational) }\end{array}$ & 1997 (sectoral) & 2007 (sectoral) \\
\hline Austria & 56.4 & 52.8 & 40.5 & 37 \\
\hline Belgium & 55 & 52.2 & 37.2 & 37.7 \\
\hline Bulgaria & n.a & 58.9 & n.a & 41.7 \\
\hline Cyprus & n.a & 58.4 & n.a & 40.7 \\
\hline Czech Republic & 60.8 & 58 & 38.6 & 40.1 \\
\hline Germany & 56 & 53.8 & 36.4 & 37 \\
\hline Denmark & 56.3 & 51.7 & 39.1 & 37.9 \\
\hline Estonia & 61.8 & 64.3 & 43.5 & 52.2 \\
\hline Greece & 45.3 & 47.2 & 32 & 33.4 \\
\hline Spain & 52.5 & 56.7 & 41.6 & 42.8 \\
\hline Finland & 59.9 & 59.2 & 44 & 46 \\
\hline France & 55.4 & 53.6 & 35 & 36.8 \\
\hline Hungary & 56.4 & 58.1 & 37.9 & 40.5 \\
\hline Ireland & 52.4 & 57 & 41.8 & 47.6 \\
\hline Island & 58.3 & 55.4 & 44.2 & 46.3 \\
\hline Italy & 46.6 & 49.4 & 32.2 & 37.2 \\
\hline Lithuania & 57.4 & 58.4 & 37.7 & 46.8 \\
\hline Luxembourg & 53.7 & 54.9 & 40.6 & 38.7 \\
\hline Latvia & 53.9 & 60.3 & 33.2 & 47 \\
\hline Malta & n.a. & 53.5 & n.a & 33.9 \\
\hline Netherlands & 53.1 & 50.8 & 39.6 & 37.9 \\
\hline Norway & 59.3 & 54.5 & 44.1 & 45.6 \\
\hline Poland & 49.8 & 52.2 & n.a. & 38.9 \\
\hline Portugal & 50.2 & 53.3 & 40.8 & 41.4 \\
\hline Romania & 43.1 & 46.8 & 29.4 & 32.4 \\
\hline Sweden & 59.7 & 54.1 & 43.8 & 42.7 \\
\hline Slovenia & 54.7 & 53.6 & 35.8 & 35 \\
\hline Slovakia & 63 & 61.4 & 42.9 & 47 \\
\hline $\mathrm{UK}$ & 55.3 & 50.9 & 38.4 & 37.5 \\
\hline EU-27 & n.a. & 50.99 & n.a. & 37.2 \\
\hline
\end{tabular}

Source: Bettio \& Verashchagina (2009)

Notes: The Duncan Segregation index is an example of an index of dissimilarity and is calculated using the following formula:

$$
I D=\frac{1}{2} \sum_{i=1}^{N}\left|\frac{m i}{M}-\frac{f i}{F}\right|
$$


where:

$\mathrm{mi}=$ the male population of the ith occupation

$\mathrm{M}=$ the total male population of the country or labor force of interest.

$\mathrm{fi}=$ the female population of the ith occupation

$\mathrm{F}=$ the total female population of the country or labor force of interest.

It is interpreted as "the percentage of females who would have to change jobs for the occupational distribution of women and men to be the same with a value of 0 indicating no segregation and a value of 100 indicating complete segregation" (Blau and Kahn, 2017).

\section{Graph A1. Histogram of the proportion of women by country and overall sample}

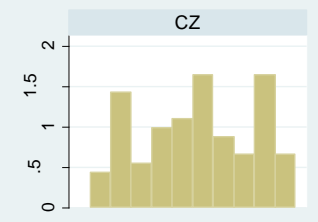

LT

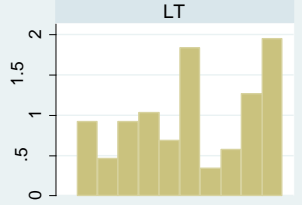

SK

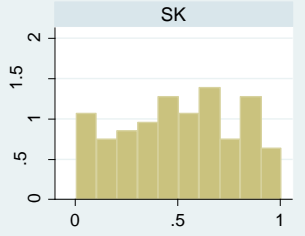

Graphs by Country
ES

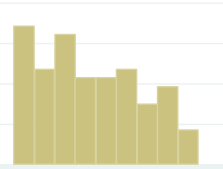

NO

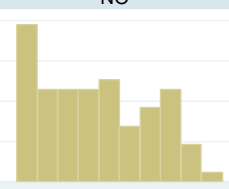

Total
FR

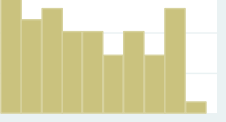

PL

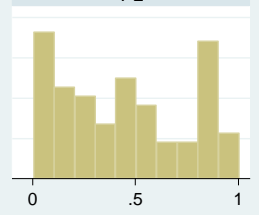

HU

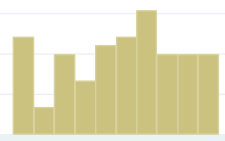

SE

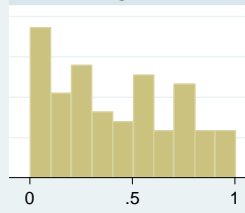

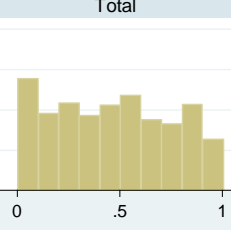

Proportion women

Note: The graph depicts the proportion of women variability between 0.01 and 1 . Occupations with zero proportion of women (male dominated occupations) have been excluded (44 occupations). 